\title{
Effects of Applying Humic Fertilizers on Tea's Yield, Nutritional Quality and Soil Fertility in a Tea Garden
}

\author{
Dongfeng Huang ${ }^{1,}$, , Limin Wang ${ }^{2, b}$, Tao Luo ${ }^{3, c}$ \\ ${ }^{1}$ Institute of Soil and Fertilizer, Fujian Academy of Agricultural Sciences, Fuzhou, 350013, China \\ ${ }^{2}$ Institute of Soil and Fertilizer, Fujian Academy of Agricultural Sciences, Fuzhou, 350013, China \\ ${ }^{3}$ Institute of Soil and Fertilizer, Fujian Academy of Agricultural Sciences, Fuzhou, 350013, China \\ a email:huangdf@189.cn, bemail:270827340@qq.com, cemail: luotaofjfz@188.com
}

Keywords: Humic acid fertilizers, Tea, Yield, Nutritional quality, Soil fertility

\begin{abstract}
A field trial with 2 kinds of humic acid fertilizers (i.e., humic acid and weathered coal) being added to the balance use of nitrogenous, phosphorus and potassium fertilizers for 3 years was carried out to test effects of tea's yield, nutritional quality and soil fertility in a tea garden. And 4 treatments were designed, i.e., (1) Chemical fertilizers (N $103 \mathrm{~kg} \cdot \mathrm{hm}^{-2} \cdot \mathrm{a}^{-1}, \mathrm{P}_{2} \mathrm{O}_{5} 34 \mathrm{~kg} \cdot \mathrm{hm}^{-2} \cdot \mathrm{a}^{-1}$ and $\mathrm{K}_{2} \mathrm{O} 34 \mathrm{~kg} \cdot \mathrm{hm}^{-2} \cdot \mathrm{a}^{-1}$, following was the same); (2) Chemical fertilizers (same as (1)) + Humic acid $\left(2000 \mathrm{~kg} \cdot \mathrm{hm}^{-2} \cdot \mathrm{a}^{-1}\right)$, (3) Chemical fertilizers (same as (1)) + weathered coal $\left(1500 \mathrm{~kg} \cdot \mathrm{hm}^{-2} \cdot \mathrm{a}^{-1}\right)$, (4) Chemical fertilizers (same as (1)) + Humic acid(1000 $\left.\mathrm{kg} \cdot \mathrm{hm}^{-2} \cdot \mathrm{a}^{-1}\right)+$ weathered $\operatorname{coal}(750$ $\mathrm{kg} \cdot \mathrm{hm}^{-2} \cdot \mathrm{a}^{-1}$ ). Results show that, under the condition of humic acid fertilizers being used in tea garden, tea's yield and tea polyphenols were increased by $3.19 \% \sim 14.24 \%$ and $5.21 \% \sim 10.73 \%$, respectively; Soil $\mathrm{pH}$, organic matter, total nitrogen, total phosphorus, total potassium, alkali-hydrolyzable nitrogen, available phosphorus and potassium were increased by 2.97\% 18.61\%, 8.86\% 27.22\%, 9.80\% 45.10\%, 6.12\% 40.82\%, 4.52\% 40.16\%, 8.81\% 45.75\%, $0.62 \% \sim 67.55 \%$ and $5.56 \% \sim 36.09 \%$, respectively. Whereas, effects of increasing tea's yield, tea polyphenols and soil alkali-hydrolyzable nitrogen by treatment of "chemical fertilizer + humic acid + weathered coal” were better than other treatments; Effects of increasing soil organic matter, total nitrogen, total phosphorus, total potassium, available phosphorus and potassium by treatment of "chemical fertilizer + humic acid" were better than other treatments; And the effect of enhancing soil pH by treatment of "chemical fertilizer + weathered coal" was better than other treatments.
\end{abstract}

\section{Introduction}

Tea production and consumption, as a kind of healthy drink, has increased sharply fast in China, recently. And its status for improving agricultural yield and peasant's incoming is increasingly prominent. As data released by Ministry of Agriculture of the People's Republic of China ${ }^{[1]}$, tea garden area and dry tea yield have been increased to 2.579 million $\mathrm{hm}^{2}$ and 1.89 million tons in 2013, grew by 16.9 ten thousands $\mathrm{hm}^{2}$ and 11.5 ten thousands tons year-on-year, respectively. The total output value of tea has reached a historical new high of RMB 110620 hundred millions yuan in China $^{[1]}$, whereas, tea's yield level of average per unit area has continued to decline in China. According to tea garden area, the average tea yield is only $732 \mathrm{~kg} \cdot \mathrm{hm}^{-2}$, reaching a year-on-year fall of $3 \mathrm{~kg} \cdot \mathrm{hm}^{-2}$, and the average tea yield is $972 \mathrm{~kg} \cdot \mathrm{hm}^{-2}$ accounted by picking tea garden area, getting a year-on-year fall of $18 \mathrm{~kg} \cdot \mathrm{hm}^{-2}$. Primary reasons leading to the above two problems are that some tea farmers pay more attention on extending tea garden's area than tea's unit yield or quality. For a long time, Chinese farmers widely adopt some extensive managements in matured tea garden, with a disconnection between land use and conservation, chemical fertilizers (mainly on nitrogen fertilizer) are blindly and excessively used, and organic fertilizers are applied rather insufficiently. Thus, some serious problems, such as soil's increasingly acidification, degradation on soil's physical and chemical characteristics, stunted growth on tea tree, decline in yield and quality of tea, and so on, are evident, which seriously hinder the sustainable utilization of soil in tea garden ${ }^{[2-3]}$. 
Soil improvers are some materials which are added into soil to improve its physical, chemical and/or biological characteristics ${ }^{[4]}$. Nowadays, humic acid and weathered coal are two kinds of soil improvers which are extensive sources, low price and easy to access ${ }^{[5,6]}$. Among them, humic acid is one kind of component complicated and inartificial organic matter which could meliorate farm soil, increase nutrients use efficiency, improve crop yield and quality, etc ${ }^{[7 \sim 11]}$. Moreover, weathered coal, which reserves up to $10^{12}$ tons, is abroad distributed at coal mine areas in China ${ }^{[12]}$, and is a kind of inartificial and nicer soil improver, which has good capability of adsorption, complexation and exchange ${ }^{[13]}$.

There are many reports about the use of humic acid and weathered coal as soil improvers, to amend soil and increase crop yield and quality ${ }^{[7 \sim 13]}$. But, it has few studies about their use on tea. In this paper, effects of applying humic acid and/or weathered coal on tea's yield, nutritional quality and soil fertility in tea garden were studied. Results will offer some scientific information on using humic acid and/or weathered coal as soil improvers on tea's production. Moreover, it will offer available references to settle some ubiquitous problems, such as soil acidification, soil physical and chemical character deterioration, tea's yield and quality descending, and so on, which are now embarrassing soil's sustainable utilization in Chinese tea garden.

\section{Materials and methods}

\section{Experimental design}

The experiment was carried out at the tea garden of Tian Xiang Tea Limited Company, which is located at Fu'an city, Fujian province in China (E119 $\left.47^{\prime} 16^{\prime \prime}, \mathrm{N}_{2} 7^{\circ} 04^{\prime} 11^{\prime \prime}\right)$. Four treatments were used, i.e.: CF - Chemical fertilizers (N $103 \mathrm{~kg} \cdot \mathrm{hm}^{-2} \cdot \mathrm{a}^{-1}, \mathrm{P}_{2} \mathrm{O}_{5} 34 \mathrm{~kg} \cdot \mathrm{hm}^{-2} \cdot \mathrm{a}^{-1}$ and $\mathrm{K}_{2} \mathrm{O} 34$ $\left.\mathrm{kg} \cdot \mathrm{hm}^{-2} \cdot \mathrm{a}^{-1}\right)$; CF+HA - Chemical fertilizers (as in (1)) +Humic acid (2000 kg $\mathrm{hm}^{-2} \cdot \mathrm{a}^{-1}$ ), CF+CA Chemical fertilizers (as in (1)) + weathered coal $\left(1500 \mathrm{~kg} \cdot \mathrm{hm}^{-2} \cdot \mathrm{a}^{-1}\right), \mathrm{CF}+\mathrm{HA}+\mathrm{CA}$ - Chemical fertilizers (as in (1)) + Humic acid $\left(1000 \mathrm{~kg} \cdot \mathrm{hm}^{-2} \cdot \mathrm{a}^{-1}\right)+$ weathered coal $\left(750 \mathrm{~kg} \cdot \mathrm{hm}^{-2} \cdot \mathrm{a}^{-1}\right)$. Each treatment had 4 replicates, arranged in a complete randomized block design, and each plot trial had an area of $20 \mathrm{~m}^{2}$. The chemical fertilizers used were Urea, Ammonium dihydrogenphosphate and Potassium chloride. The humic acid was produced by Fujian Zaoan Lv Zhou Biochemical Co., Ltd. And the weathered coal was supplied by Chaoda Modern Agricultural Group. Trial tea breed was Huang Guan Yin with 4 years old. Trial period was from March, 2010 to November, 2012. All chemical fertilizers and/or soil improvers for each trial plot were completely mixed and groove fertilized one-off into soil between tree lines during the middle of March each year.

Yield of tea leaves was yearly registered, during the trial period. Tea leaves samples for quality test were plucked by " $S$ " route at each trial plot on the Apr.26 ${ }^{\text {th }}, 2012$. Surface soil samples (0 20 $\mathrm{cm})$ were collected by "S" route in each trial ploton the Nov. $3^{\text {rd }}, 2012$.

\section{Determining method}

Soil fertility indexes were determined by using routine assaying methods ${ }^{[14]}$, i.e.: $\mathrm{pH}$ was measured by using potentiometry (the rate of soil and water was 1:2.5); Organic matter used potassium dichromate method; Total $\mathrm{N}$ used Semi-micro Kjeldahl method; Total P used Molybdenum Blue Spectrophotometry; Total K used flame photometry; Alkaline hydrolysable N used alkali N-proliferation method; Available P used Molybdenum Blue Spectrophotometry after distilling by $0.05 \mathrm{~mol} \cdot \mathrm{L}^{-1} \mathrm{NaHCO}_{3}$; Available $\mathrm{K}$ used flame photometry. Tea leaves' quality was assayed by using Chinese national standard methods, i.e.: Tea Polyphenols used GB/T8313-2002; Water extract used GB/T8305-2002, Theine use GB/T8312-2002, Soluble sugar used GB/T8305-2002.

\section{Data processing}

Trial data were processed by Microsoft Excel-2003. And for data analysis it was used the statistic software SPSS10.0. 


\section{Results and Analysis}

\section{Effect of using different kinds of humic acid fertilizers on tea's yield}

Results (Fig.1) showed that, compared with treatment CF, tea leaves' yield of other 3 treatments might increase by $3.19 \% \sim 14.24 \%$ or $112 \sim 500 \mathrm{~kg} \cdot \mathrm{hm}^{-2} \cdot \mathrm{a}^{-1}$. Results of variance analysis indicated that, for increasing tea's yield, treatment of $\mathrm{CF}+\mathrm{HA}+\mathrm{CA}$ was significantly better $(P<0.05)$ than $\mathrm{CF}$, but it had not significant $(P \geq 0.05)$ difference between $\mathrm{CF}+\mathrm{HA}$ and $\mathrm{CF}+\mathrm{CA}$.

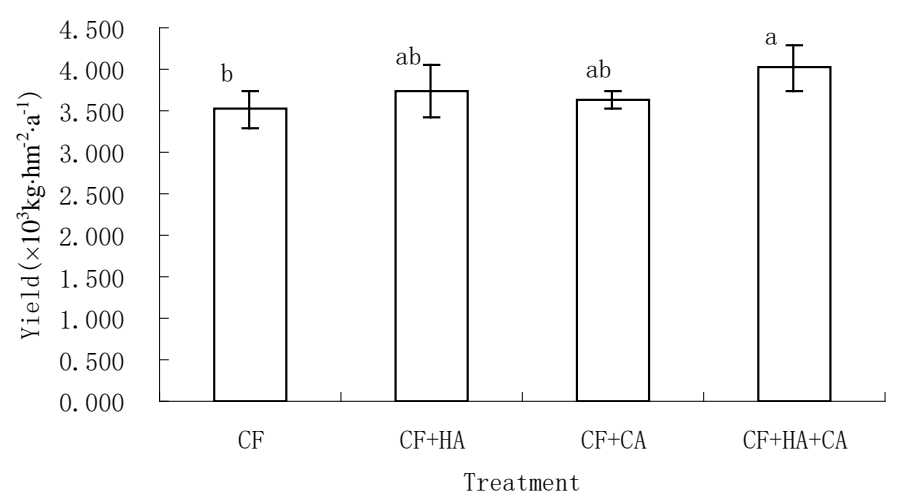

Fig.1 Effect of using different kinds of humic acid fertilizers on tea's yield Note: Different small letters above columniation stand for significant difference $(P<0.05) \quad$ in above figure.

\section{Effect of using different kinds of humic acid fertilizers on tea's quality}

Results (tab.1) showed that: Compared with treatment CF, tea leaves' Tea polyphenols, Water abstract, Theine and soluble sugar could increase by 5.21\% 10.73\%, 2.61\% 7.24\%, 0.00\% 2.36\% and $1.07 \% \sim 6.64 \%$, respectively. Results of variance analysis indicated that: for increasing tea's Tea polyphenols, treatments of $\mathrm{CF}+\mathrm{HA}+\mathrm{CA}$ and $\mathrm{CF}+\mathrm{HA}$ were notably better $(P<0.05)$ than $\mathrm{CF}$, but $\mathrm{CF}+\mathrm{CA}$ had not significant $(P \geq 0.05)$ difference with CF; For increasing tea's Water abstract, Theine or Soluble sugar, all designed treatments had not significant difference $(P \geq 0.05)$.

Tab.1 Effect of using different kinds of humic acid fertilizers on tea's quality

\begin{tabular}{|c|c|c|c|c|c|c|c|c|}
\hline \multirow[b]{2}{*}{ Treatments } & \multicolumn{2}{|c|}{ Tea polyphenols } & \multicolumn{2}{|c|}{ Water abstract } & \multicolumn{2}{|c|}{ Theine } & \multicolumn{2}{|c|}{ Soluble sugar } \\
\hline & $\begin{array}{c}\text { Content } \\
/ \%\end{array}$ & $\begin{array}{c}\text { Compare } \\
\text { d with } \\
\text { CF/\% }\end{array}$ & $\begin{array}{c}\text { Content } \\
\quad / \%\end{array}$ & $\begin{array}{c}\text { Compare } \\
\text { d with } \\
\text { CF/\% }\end{array}$ & $\begin{array}{c}\text { Content } \\
/ \%\end{array}$ & $\begin{array}{c}\text { Compare } \\
\text { d with } \\
\text { CF } / \%\end{array}$ & $\begin{array}{c}\text { Content } \\
/ \%\end{array}$ & $\begin{array}{c}\text { Compare } \\
\text { d with } \\
\text { CF/\% }\end{array}$ \\
\hline $\mathrm{CF}$ & $9.60 \mathrm{~b}$ & - & 50.11a & - & $3.81 \mathrm{a}$ & - & $4.67 \mathrm{a}$ & - \\
\hline $\mathrm{CF}+\mathrm{HA}$ & $10.51 a$ & 9.48 & $52.40 \mathrm{a}$ & 4.57 & 3.89a & 2.10 & 4.98a & 6.64 \\
\hline $\mathrm{CF}+\mathrm{CA}$ & 10.10ab & 5.21 & $51.42 \mathrm{a}$ & 2.61 & 3.81a & 0.00 & $4.72 \mathrm{a}$ & 1.07 \\
\hline $\begin{array}{l}\mathrm{CF}+\mathrm{HA}+\mathrm{C} \\
\mathrm{A}\end{array}$ & $10.63 a$ & 10.73 & $53.74 a$ & 7.24 & $3.90 \mathrm{a}$ & 2.36 & $4.85 a$ & 3.85 \\
\hline
\end{tabular}

Note: Different small letters after data stand for significant difference $(P<0.05)$ in above table.

Effect of using different kinds of humic acid fertilizers on soil chemical characters in tea garden

Results (tab.2) showed that: Compared with treatment CF, other 3 treatments all could improve soil basic chemical properties to some extent. For example, soil pH, Organic matter, Total nitrogen, Total phosphorus, Total potassium, Alkaline hydrolysable nitrogen, Available phosphorus and Available potassium could increase by $2.97 \% \sim 18.61 \%$, 8.86\% 27.22\%, 9.80\% 45.10\%, 6.12\% 40.82\%, 4.52\% 40.16\%, 8.81\% 45.75\%, 0.62\% 67.55\% and 5.56\% 36.09\%, respectively. Results of variance analysis indicated that: for increasing soil's Organic matter, Total nitrogen, Total phosphorus, Total potassium, Available phosphorus and Available potassium, treatment of CF+HA could very significantly $(P<0.01)$ better than $\mathrm{CF}$, and significantly $(P<0.05)$ better than $\mathrm{CF}+\mathrm{CA}$, but had not significant difference for increasing soil $\mathrm{pH}$ or Alkaline hydrolysable nitrogen; For enhancing soil $\mathrm{pH}, \mathrm{CF}+\mathrm{CA}$ could significantly $(P<0.05)$ better than $\mathrm{CF}$, but had not significant $(P \geq 0.05)$ difference with $\mathrm{CF}+\mathrm{CA}$ and $\mathrm{CF}+\mathrm{HA}+\mathrm{CA}$; for increasing soil Alkaline hydrolysable 
nitrogen, treatment of $\mathrm{CF}+\mathrm{HA}+\mathrm{CA}$ could very significantly $(P<0.01)$ better than $\mathrm{CF}+\mathrm{HA}$ and $\mathrm{CF}$, and significantly $(P<0.05)$ better than $\mathrm{CF}+\mathrm{CA}$

Tab.3 Effect of using different kinds of humic acid fertilizers on soil chemical characters in tea garden.

\begin{tabular}{|c|c|c|c|c|c|c|c|c|c|}
\hline \multirow[t]{2}{*}{ Treatment } & \multirow[t]{2}{*}{$\mathrm{pH}$} & \multicolumn{4}{|c|}{ Organic matter } & \multicolumn{2}{|c|}{ Total nitrogen } & \multicolumn{2}{|c|}{$\begin{array}{c}\text { Alkaline } \\
\text { hydrolysable } \\
\text { nitrogen }\end{array}$} \\
\hline & & $\begin{array}{l}\text { Compare } \\
\text { d with } \\
\text { CF /\% }\end{array}$ & $\begin{array}{l}\text { Conten } \\
\quad \mathrm{t} / \\
\left(\mathrm{g} \cdot \mathrm{kg}^{-1}\right)\end{array}$ & & $\begin{array}{l}\text { pare } \\
\text { ith } \\
\text { /\% }\end{array}$ & $\begin{array}{l}\text { Content/ } \\
\left(\mathrm{g} \cdot \mathrm{kg}^{-1}\right)\end{array}$ & $\begin{array}{l}\text { Compare } \\
\text { d with } \\
\text { CF } / \%\end{array}$ & $\begin{array}{l}\text { Content } \\
/ \\
\left(\mathrm{mg} \cdot \mathrm{kg}^{-1}\right. \\
)\end{array}$ & $\begin{array}{l}\text { Compar } \\
\text { ed with } \\
\text { CF } / \%\end{array}$ \\
\hline $\mathrm{CF}$ & $5.05 \mathrm{~b}$ & - & $15.8 \mathrm{Bb}$ & & 0 & $0.51 \mathrm{Bb}$ & - & $47.65 \mathrm{Bc}$ & - \\
\hline $\mathrm{CF}+\mathrm{HA}$ & $5.20 \mathrm{ab}$ & 2.97 & 20.1Aa & & 22 & $0.74 \mathrm{Aa}$ & 45.10 & $\begin{array}{c}51.85 \mathrm{Bb} \\
\mathrm{c}\end{array}$ & 8.81 \\
\hline $\mathrm{CF}+\mathrm{CA}$ & $5.99 a$ & 18.61 & $\begin{array}{c}17.2 \mathrm{~A} \\
\mathrm{Bb}\end{array}$ & & 86 & $0.56 \mathrm{ABb}$ & 9.80 & $\begin{array}{l}55.98 \mathrm{~A} \\
\mathrm{Bb}\end{array}$ & 17.48 \\
\hline $\begin{array}{l}\mathrm{CF}+\mathrm{HA}+ \\
\mathrm{CA}\end{array}$ & 5.69a & 12.67 & $\begin{array}{c}19.3 \mathrm{~A} \\
\mathrm{Ba} \\
\end{array}$ & & 15 & $0.68 \mathrm{ABa}$ & 33.33 & 69.45Aa & 45.75 \\
\hline \multirow[t]{2}{*}{ Treatment } & \multicolumn{2}{|c|}{ Total phosphorus } & \multicolumn{3}{|c|}{ Available phosphorus } & \multicolumn{2}{|c|}{ Total potassium } & \multicolumn{2}{|c|}{$\begin{array}{l}\text { Available } \\
\text { potassium }\end{array}$} \\
\hline & $\begin{array}{l}\text { Conten } \\
\quad \mathrm{t} / \\
\left(\mathrm{g} \cdot \mathrm{kg}^{-1}\right)\end{array}$ & $\begin{array}{l}\text { Compar } \\
\text { ed with } \\
\text { CF } / \%\end{array}$ & $\begin{array}{l}\text { Conte } \\
(\mathrm{mg} \cdot \mathrm{k}\end{array}$ & & $\begin{array}{l}\text { Compare } \\
\text { d with } \\
\text { CF } / \%\end{array}$ & $\begin{array}{c}\text { Conten } \\
\mathrm{t} / \\
\left(\mathrm{g} \cdot \mathrm{kg}^{-1}\right)\end{array}$ & $\begin{array}{l}\text { Compar } \\
\text { ed with } \\
\text { CF /\% }\end{array}$ & $\begin{array}{c}\text { Content } \\
/ \\
\left(\mathrm{mg} \cdot \mathrm{kg}^{-1}\right. \\
)\end{array}$ & $\begin{array}{l}\text { Compar } \\
\text { ed with } \\
\text { CF /\% }\end{array}$ \\
\hline $\mathrm{CF}$ & $0.49 \mathrm{Bb}$ & - & 41.85 & & - & $\begin{array}{c}19.25 \\
\mathrm{Bb}\end{array}$ & - & $\begin{array}{c}180.21 \\
\mathrm{Bb}\end{array}$ & - \\
\hline $\mathrm{CF}+\mathrm{HA}$ & 0.69Aа & 40.82 & 70.12 & & 67.55 & $\begin{array}{c}26.98 \\
\mathrm{Aa}\end{array}$ & 40.16 & $\begin{array}{c}245.24 \\
\mathrm{Aa}\end{array}$ & 36.09 \\
\hline $\mathrm{CF}+\mathrm{CA}$ & $0.52 \mathrm{Bb}$ & 6.12 & 42.11 & & 0.62 & $\begin{array}{c}20.12 \\
\mathrm{Bb}\end{array}$ & 4.52 & $\begin{array}{c}190.23 \\
\mathrm{Bb}\end{array}$ & 5.56 \\
\hline $\mathrm{CF}+\mathrm{HA}+\mathrm{CA}$ & $0.65 \mathrm{Aa}$ & 32.65 & 68.01 & & 62.51 & $\begin{array}{c}23.14 \\
\mathrm{Aa}\end{array}$ & 20.21 & $\begin{array}{l}203.45 \\
\mathrm{Aa}\end{array}$ & 12.90 \\
\hline
\end{tabular}

\section{Discussion and conclusion}

\section{Effect of using different kinds of humic acid fertilizers on tea's yield and quality}

Humic acid is one important organic segment for most soil, and it can separate into some sorts, such as turf, lignite, weathered coal, and so on, according to its different sources ${ }^{[15]}$. Several trial results have shown that applying humic acid fertilizers (or soil improvers) could increase tea's yield or quality. Yang et al's result ${ }^{[16]}$ showed that, compared with CK(spraying water), spraying humic acid fertilizer (the content of sodium humate was 8\%) on 6 year-old tea trees could increase tea's yield by $8.9 \%$, enhance tea's amino acid by $12.0 \%$, theine by $6.9 \%$, water exact by $5.9 \%$. Chen et al's result ${ }^{[17]}$ showed that, tea leaves' yield increased by $4.32 \% \sim 12.62 \%$ after using humic acid fertilizer $\left(75 \sim 1200 \mathrm{~kg} \cdot \mathrm{hm}^{-2}\right)$. Peng et al's result ${ }^{[5]}$ showed that, watering humic acid fertilizer (diluted by 500 times) on tea trees, tea's yield might increase 6.5\% 18.8\%; and the effect of using fulvic acid was better than potassium humate. Our field trial's results showed that, under the condition of 2 kinds of soil improvers (i.e., humic acid and weathered coal) being added to the balance use of nitrogenous, phosphorus and potassium fertilizers in tea garden, tea's yield was increased by 3.19\% 14.24\%, tea polyphenols, water exact, theine and soluble sugar were enhanced by $5.21 \% \sim 10.73 \%, 2.61 \% \sim 7.24 \%, 0.00 \% \sim 2.36 \%$ and $1.07 \% \sim 6.64 \%$, respectively.

\section{Effect of using humic acid fertilizers on soil chemical characters in tea garden}

Study on effects of using humic acid fertilizers (soil improvers) on soil basic fertility in tea 
garden was less covered. Chen et al's result ${ }^{[17]}$ showed that, soil $\mathrm{pH}$ was enhanced gradually by $4.50 \% \sim 14.19 \%$ with the increasing of using rates of humic acid fertilizer(75 1200 kg/hm²), but the contents of soil organic matter, alkaline hydrolysable nitrogen, available phosphorus and available potassium were not significantly different with CK, it might for the relative short trial period (less than 1 year). Our results concluded from about 3 years trial period showed that, under the condition of soil improvers being used in tea garden, soil $\mathrm{pH}$, organic matter, total nitrogen, total phosphorus, total potassium, alkali-hydrolyzable nitrogen, available phosphorus and potassium were increased by $\quad 2.97 \% \sim 18.61 \%, \quad 8.86 \% \sim 27.22 \%, \quad 9.80 \% \sim 45.10 \%, \quad 6.12 \% \sim 40.82 \%, \quad 4.52 \% \sim 40.16 \%$, 8.81\% 45.75\%, 0.62\% 67.55\% and 5.56\% 36.09\%, respectively.

Tea leaves' yield and quality, soil's basic fertility can be effectively increased or improved by using humic acid fertilizers (soil improvers) into tea garden. The main reasons are as follows: (1) Humic acid is a kind of inartificial organic large molecule, which is mostly made up of $\mathrm{C}, \mathrm{H}, \mathrm{O}, \mathrm{N}$, $\mathrm{S}$ and other elements ${ }^{[15]}$. This large molecule may supply abundant nutrient elements for tea tree after being naturally mineralized and decomposed by microorganisms. Those abundant nutrient elements are essential for increasing tea's yield and quality. (2) Humic acid is a kind of macromolecule organic colloid, which contains many kinds of oxygen-containing functional groups. So, it has some special characteristics, such as, weak acid, absorbent, ion exchangeability, complexation, buffer, redox and biological activity for plant, etc ${ }^{[18-19]}$. Moreover, humic acid is rich in Humic acid and Fulvic acid, which are closely relative to some soil's properties, such as fertilizer retention, water and temperature retention, buffering, tilth, ventilation condition, etc. Therefore, applying humic acid fertilizers (soil improvers) into tea garden can construct good soil eco-environment for increasing tea leaves' yield and quality by improving soil's basic fertility and enhancing its self regulating ability to water, fertilizer, gas and heat ${ }^{20]}$. (3) Humic acid can activate soil's nutrients and increase their biological availability. For example, Humate and Nitrohumic acid both can restrain soil fixing phosphorus to some extent. Using humic acid will promote plants to absorb nutrients for promoting difficult soluble elements' dissolution or chelation ${ }^{[19]}$. (4) Humic acid can increase chemical fertilizer's use efficiency. Some reasons are concluded as follows: Firstly, humic acid can obviously inhibit nitrification and promote plant to uptake nitrogen ${ }^{[18]}$. Secondly, adding humic acid into available phosphorus fertilizers would obviously inhibit soil fixing phosphorus and increase phosphorus fertilizers' utilization rate, because humic acid has a strong affinity for some ions, such as, iron, aluminium, calcium, etc ${ }^{[18]}$. Thirdly, potassium is easily fixed into crystal lattices of some colloidal particles like montmorillonite and change into slowly available potassium or invalid potassium, while chemical potassium fertilizers are applied into soils which are rich in clay minerals. And, while chemical potassium fertilizers are applied into arenosols, potassium is easy to be loss. Otherwise, chemical fertilizers mixed with humic substances could effectively prevent potassium being fixed or lost, then obviously improve potassium fertilizers' utilization rate ${ }^{[18]}$. (5)Using humic acid fertilizers may promote soil microbial breeding, regulate soilmicroorganisms' population structure, activate microbial enzymes, boost microorganisms' decomposing or composing, and increase soil nutrient's conversion and supply capacity ${ }^{[20]}$.

To sum up, results concluded from our trial showed that humic acid fertilizers (i.e., humic acid and weathered coal) being added to the balance use of nitrogenous, phosphorus and potassium fertilizers would preferably increase tea leaves' yield and quality and obviously improve tea garden soil's basic fertility in the red soil area of China. Whereas, effects of increasing tea's yield, tea polyphenols and soil alkali-hydrolyzable nitrogen by treatment of "chemical fertilizer + humic acid + weathered coal" were better than other treatments; Effects of increasing soil organic matter, total nitrogen, total phosphorus, total potassium, available phosphorus and potassium by treatment of "chemical fertilizer + humic acid" were better than other treatments; and the effect of enhancing soil pH by treatment of "chemical fertilizer + weathered coal" was better than other treatments.

\section{Acknowledgements}

Above works were supported by National Key Technology Research and Development Project of the Ministry of Science and Technology of China (2015BAD05B01-05, 2012BAD14B15-6); 
Special Project of Fundamental Research Funds for Public Welfare Research Institutes of Fujian Province (2014R1022-7).

\section{References:}

[1]Tea company of Quanzhou city. Chinese tea plant and production in 2013 issued by Ministry of agriculture of the People's Republic of China [ EB / OL]. http : // www. fjcoop. Com / html / 1 / 8 / 49249 2014 12 058_1.html. 2014-01-20

[2] HUANG Dong-feng, LI Wei-hua, FANG Ping, et al. Countermeasures of low-carbon economy for sustainable development of China's tea industry[J]. Chinese Journal of Eco-Agriculture, 2010,18(5): 1110-1115

[3] WANG Jiao-chang. Opinions on the management of tea field fertility[J]. Guizhou Science, 2008,26(2): 44-47

[4] SUN Ji-feng, WANG Xu. Advance in research and application of soil conditioner[J]. Soils and Fertilizers Sciences in China, 2013 (1):1-7

[5] PENG Zhi-dui, HUANG Ji-chuan, YU Ju-hong, et al. Effects of humic acid fertilizer on yield and quality of tea[J]. Guangdong Agricultural Sciences,2012,(22):6 8

[6] WANG Ri-Xin, LI Cheng-xue. Green humic acid phosphate fertilizer[M]. Beijing: Chemical Industry Press, 2009

[7] GAO Yu-feng, SUN Li-rong, ZHOU Li-na, et al. Effect of fulvic acid fertilizer on improving soil’s characteristics[J]. Shaanxi Journal of Agricultural Sciences, 2011(6):100-103

[8] CHEN Fu-sheng, CHEN Guang-sheng, ZENG De-hui, et al. Effects of peat and weathered coal on the growth of Pinus sylvestris var. mongolica seedlings on aeolian sandy soil[J]. Journal of Forestry Research, 2002,13(4): 251-254

[9] BAI Ling, CHEN Shi-bao, HUA Luo, et al. Studies on characteristics of complexation of Cd and Zn with humic acids[J]. Acta Agriculturae Nucleatae Sinica, 2000,14(1):44-48

[10]YAMAGUCHI T. Effect of peat-sapropel based ameliorant on green cabbage and wheat cultivation in the Egyptian Western Desert[J]. Journal of Arid Land Studies, 1997,7(1):35-45

[11] YAMAGUCHI T. Prevention of desertification by utilizing natural humic resources found nearby the site [J]. Journal of Arid Land Studies. 1999,9(1):105-122

[12]WEN Ya, LI Dong-Xu. The applications of weathered coal humic acid in soil amelioration[J]. Sci-Tech Information Development \& Economy, 2010,20(33):148-149

[13]WU Rui-ping, LI Hua, CAO Peng. Amelioration of weathered coal on soil physical, chemical properties and enzyme activities with vegetation restoration[J]. Journal of Agro-Environment Science, 2009,28(9):1855-1861

[14] Chinese society of soil. Analysis method of soil agricultural chemistry[M]. Beijing: China Agriculture Sci-tech. Press, 2000

[15] HUAN Ming-dong, YANG Shuan, DUAN Zhen-yu. Effects of humic acid on soil improvement[J]. Agriculture \& Technology, 2013,3(3):5

[16]YANG Jing-yu, HAI Jian-ping, ZHAO Li-jun. Analysis on the effects of new water soluble fertilizers on tea production and economic benefits[J]. Horticulture \& Seed, 2012, (4):56-59

[17]CHEN Xue-tao, MA Xian-fa, Zhang Ji-zhou. Effect of applying humic acid fertilizer on the Tieguanyin tea tree[J]. Fujian Agricultural Technology, 2014,(4):24-26

[18]WANG Hong-tao, MA Xian-fa, ZHANG Ji-Zhou. Application of humic acid in soil and fertilizer[J]. Heilongjiang Science,2010,1(1):59-62

[19] ZHAO Hong-liang, ZOU De-yi. Improvement effect of humic acid on the sand[J]. Humic Acid, 2008,(3):45-46

[20] ZOU De-yi. Humic acid soil quality improver[J]. Humic Acid, 2008,(2):44-45 